УДК 378.1

UDC 378.1

DOI: $10.31475 /$ ped.dys.2019.27.09

\author{
СЕРГІЙ ВОЛОШИНОВ, \\ кандидат педагогічних наук, доцент \\ (Україна, Херсон, Херсонська державна морська академія, \\ проспект Ушакова, 20) \\ SERHII VOLOSHYNOV, \\ Candidate of Pedagogical Sciences, Associate Professor \\ (Ukraine, Kherson, Kherson State Maritime Academy, \\ Ushakov Avenue, 20) \\ ORCID: 0000-0001-7436-514X
}

\title{
Аналіз підходів та засобів навчання у морських закладах освіти за кордоном
}

\section{Analysis of Approaches and Teaching Tools in Maritime Educational Institutions Abroad}

У статті здійснено аналіз сучасного стану морської освіти за кордоном. Проаналізовано дослідження щодо профбесійної підготовки морських фбахівців за кордоном і зроблено висновок про не достатне висвітлення питання дослідження підходів та засобів навчання у морських освітніх закладах за кордонол, що спряловані на підвищення ефбективності морської освіти. Висвітлено значення таких міжнародних інститутів як Міжнародна асоціація морських університетів та Міжнародний морський університет в удосконаленні проббесійної підготовки майбутніх морських фбахівців. Проаналізовано дослідження щодо проблел удосконалення профбесійної підготовки морських ббахівиів у краӥнах, що розвиваються (Південна Аббрика, В’єтнам). Визначено, що для удосконалення профбесійної підготовки майбутніх морських ббахівиів в Україні можуть бути використані такі підходи як міждисциплінарний, дуальний, інфбормативний, дослідницький, інтегративний, а також приниип мобільності. Як ефективні засоби навчання визначено засоби віртуальної та доповненої реальності, мобільні технологї та дистанційне навчання.

Ключові слова: зарубіжний досвід, профбесійна підготовка, морські фбахівиі, четверта промислова революиія (4.0).

The article analyzes the current state of maritime education abroad. The study on the training of maritime specialists abroad is analyzed and the conclusion is made that the issue of research on approaches and means of training in maritime educational institutions abroad, aimed at improving the efficiency of maritime education, is not adequately covered. The importance of such international institutes as the International Association of Maritime Universities and the International Maritime University in improving the professional training of future maritime professionals is highlighted. It is revealed that the International Association of Maritime Universities is paying attention to the problems of the impact of virtual reality on maritime education and training, including the coverage of how to apply virtual reality in the training of maritime professionals. It is determined that the main content of the educational programs of the International Maritime University is the educational and research problems. Studies on the challenges of improving the training of maritime professionals in developing countries (South Africa, Vietnam) are analyzed. Some recommendations that may be appropriate for introducing Ukraine's maritime education as a country undergoing a process of reforming the national education system are presented. Methods such as analysis, synthesis, comparison, generalization were used to achieve the goal. It has been established that the emphasis is on developing the digital skills of future maritime professionals and implementing the requirements of the 4th Industrial Revolution into maritime education and training. It is determined that to improve the professional training of future maritime specialists in Ukraine such approaches as interdisciplinary, dual, informative, research, integrative, as well as the principle of mobility can be used. As the result, virtual and augmented reality, mobile technologies and distance learning are identified as effective learning tools.

Key words: foreign experience, professional training, maritime specialists, fourth industrial revolution (4.0).

Вступ / Introduction. Для ефективного функціонування світової морської індустрії важливим e вплив людський фактору, а отже освіта і підготовка висококваліфікованих морських фахівців. Вимоги до якості морської освіти визначаються Міжнародною морською організацією (далі - IMO), що орієнтуе освітні заклади на удосконалення професійної підготовки морських фахівців 
відповідно до сучасних вимог галузі й інформаційного суспільства. Міжнародна морська організація мае в своему складі 170 держав і розділена на п'ять комітетів за напрямками діяльності. Питаннями освіти займаеться підкомітет з підготовки кадрів в рамках Комітету 3 безпеки мореплавання. Міжнародна морська організація діє як спеціалізована установа Організації Об’еднаних Націй. Стандарти освіти були сформульовані в Міжнародній конвенції про підготовку і дипломування моряків та несення вахти (International Convention for the Standards of Training, Certification and Watchkeeping), яка зазнавала поправок у 1995 та 2010 pp. (International Maritime Organization, 2017).

У 2018 р. Україна підписала Меморандум про співпрацю з Міжнародною морською організацією щодо участі у Системі аудиту держав - членів Міжнародної морської організації (International Association of Maritime Universities, 2004). Також у 2018 р. Україна вперше пройшла обов’язковий аудит Міжнародної морської організації, який підтвердив виконання державою Україна міжнародних зобов'язань у сфері безпеки судноплавства.

Нині важливим стає вивчення підходів, засобів, методів навчання у закордонних закладах вищої морської освіти, що спрямовані на підвищення ефекктивності професійної підготовки морських фахівців, та їх впровадження у практику викладання. Це допомагае не лише підвищенню якості морської освіти в Україні, а й у свою чергу сприяе стабільному підвищенню безпеки на морі та вирішенню проблем із впливом людського фактору у морській промисловості.

Дослідженню професійної підготовки морських фрахівців закордоном присвячено наукові доробки таких дослідників: М. Макаренко, О. Носовська, А. Кравченко, Л. Кошарська, В. Бредньова, A. Levitscy, В. Єфентьева та ін.

Зокрема М. Макаренко, О. Носовська, А. Кравченко на основі проведених досліджень зазначають, що провідними країнами постачальниками робочої сили на торгові судна е Китай, Філіппіни, Індія, Україна, Росія та Індонезія, що усі ці країни мають освітні заклади, що покликані здійснювати підготовку кваліфікованих працівників для світового судноплавства. Однак, рівень освіти в цих країнах дуже різний. Так, якість освіти у Філіппінах значно нижче, ніж в Росії та Україні, а КНР випереджае Індію за якістю та практичною підготовкою майбутнього плавскладу (Макаренко М., Носовська О., \& Кравченко А., 2017).

Л. Кошарська, В. Бредньова, А. Левіцкі слушно зазначають, що світовий досвід морських освітніх закладів показуе недостатність піклування про морську освіту з боку Міністерства освіти і науки та Міністерства транспорту України. Удосконалення національної морської освіти можливе лише у тісній співпраці із судноплавними компаніями (Кошарська Л., Бредньова B., \& Levitscy A., 2019).

Мета та завдання / Aim and Tasks. Більшість досліджень з вивчення зарубіжного досвіду морської освіти мають загальний характер, тому аналізу й узагальнення вимагае питання дослідження підходів та засобів навчання у морських навчальних закладах закордоном, що спрямовані на підвищення ефективності професійної підготовки морських фрахівців.

Методи / Methods. Для досягнення мети у дослідженні було використано такі методи як аналіз, синтез, порівняння, узагальнення (для вивчення та узагальнення наукової літератури 3 конкретно-наукової методології проблеми, виявлення позитивного зарубіжного досвіду для удосконалення морської освіти).

Результати / Results. У морській освіті існуе практика обговорення освітніх програм і їх реалізації у морській індустрії з використанням міжнародних інститутів. Одним 3 таких $є$ Міжнародна асоціація морських університетів (International Association of Maritime Universities IAMU), що е глобальною мережею морських університетів 3 підготовки морських фрахівців. Структура IAMU складаеться з щорічної Генеральної Асамблеї, Міжнародної виконавчої ради, постійних комітетів та Секретаріату (рис. 1). Університетами-засновниками асоціації у 1999 р. стали такі заклади як Арабська академія науки і техніки та морського транспорту (Африка), Австралійський морський коледж (Океанія), Кардіффрський університет (Західна Європа), Стамбульський технічний університет, морський фракультет (Середземномор'я), Університет торговий морський Кобе (Азія), Морська академія Мен (Америка, включаючи Кариби), Всесвітній морський університет (загальне представництво). Станом на квітень 2019 р. асоціація включає 66 членів з 35 країн.

Основними напрямками діяльності, як Міжнародної асоціації морських університетів в цілому, так і окремих морських університетів е глобалізація i всебічний розвиток морської освіти 3 предметним поглибленням теоретичних основ при одночасному розширенні їх практичного застосування у вирішенні конкретних професійних завдань.

Усі члени асоціації визнають значення морської освіти та зазначають, що: галузь судноплавства - це галузь послуг, в якій людські ресурси е найважливішим елементом; забезпечити та зберегти висококваліфіковані кадрові ресурси в морській промисловості можливо 
лише шляхом ефективної освіти та навчання; ефективна освіта та навчання в морському секторі бере початок у науковій та академічній частині та дотриманні чіткого зв'язку між практичними навичками, технікою управління та орієнтацією на якість (About IAMU, 2019). У своїх наукових публікаціях та звітах IAMU приділяе увагу питанням удосконалення профресійної підготовки майбутніх морських фрахівців. Зокрема у звіті «Переосмислення морської педагогіки - наслідки віртуальної реальності у морській освіті та навчанні» (Redefining Seafaring Pedagogy - Impacts of Virtual Reality on Maritime Education and Training) подано не лише аналіз основних переваг віртуальної реальності (ВР), можливостей їі використання у морській підготовці, ролі викладача у віртуальному середовищі, а й запропоновано ВР системи та додатки для навчання, у тому числі на смартфонах, розробки уроків з використанням ВР, методика застосування ВР у професійній підготовці морських фрахівців тощо (Redefining Seafaring Pedagogy, 2017).

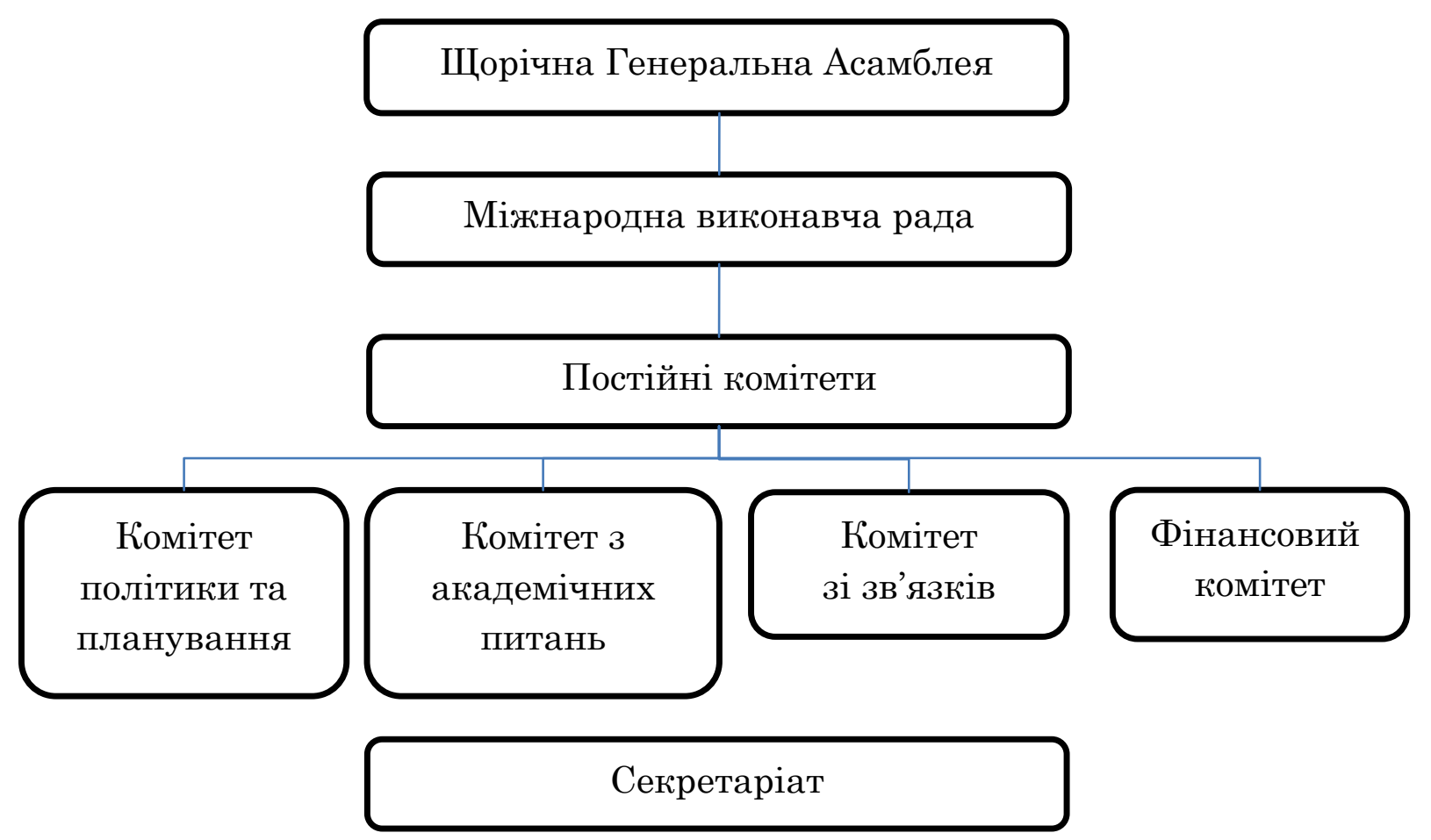

Рис. 1 Структура Міжнародної асоціацї морських університетів

Серед морських університетів світу особливе положення займає Міжнародний морський університет (World Maritime University - WMU) у Швеції. Заснований в 1983 р. нині він дотримуеться восьми стратегічних напрямів (MSc and Phd in Maritime Affairs taught in Malmo, 2018), саме:

1) навчання та виховання морських лідерів,

2) посилене викладання морської політики,

3) розширення питань, пов'язаних з океанами,

4) розширення морських та океанських досліджень,

5) диверсифікація генерації доходів,

6) нові шляхи співпраці,

7) подальша співпраця з IMO,

8) створення фронду підтримки.

3 самого початку в університет приймалися молоді люди, які закінчили морський навчальний заклад (postgraduates) вже з деяким досвідом роботи на суднах або в різних системах їх берегового обслуговування. Спочатку на дворічних навчальних курсах продовжували освіту в трьох напрямках: суднова енергетика (Maritime Engineering Trading - MET), навігація та берегове обслуговування судноплавства. Згодом технічні дисципліни з навчальних і дослідницьких програм університету були виключені. Головним принциповим їх змістом залишилися навчальні та дослідницькі проблеми. Серед них (Костылев И., \& Овсянников М., 2015):

- постійне вивчення та аналіз сучасного стану світового транспортного фрлоту в усіх сфрерах практичної діяльності, а також можливих найближчих і подальших перспектив його розвитку;

- розробка і впровадження пакетів консультаційного обслуговування об'єктів фрлоту і морських навчальних закладів е рамках міжнародного співробітництва, зокрема в галузі навчальних 
програм морських університетів;

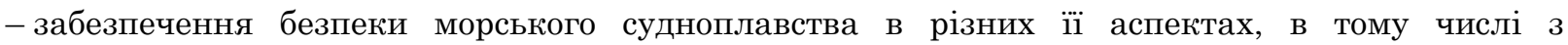
організації специфічного менеджменту в сфері захисту навколишнього середовища i трудових ресурсів;

- захист і розвиток сприятливих умов праці на флоті;

- робота по зміцненню статусу університету як світового центру організації морської освіти і досліджень в області судноплавства.

На наш погляд заслуговують на увагу також дослідження щодо проблем удосконалення професійної підготовки морських фрахівців у країнах, що розвиваються. Адже, деякі рекомендації, що у них подаються, можуть бути доцільними для України, як країни, що зазнае процесу реформування вітчизняної системи освіти. Зокрема у дослідженні L. A. Ngcobo (Ngcobo L. A., 2018) стосовно морської освіти у Південній Африці зазначаеться, що у південноафриканських навчальних закладах бракуе курсантів, які мають цифрову підготовку і будуть готові зайняти свої місця на міжнародному ринку праці. Тому пропонуеться кілька рекомендацій, що містять практичні дії для дослідження та впровадження й в Україні, а саме:

1. Проведення аудиту результатів навчання морських фахівців. Це має велике значення для створення бази даних кваліфікованих морських фахівців, які відповідають запланованим результатам навчання. Після того як комплексний аудит буде завершений, буде зрозуміло, які компетентності потрібні для руху вперед та яким потрібно приділити більше уваги.

2. Нарощування потенціалу та освітніх ресурсів з точки зору обладнання та інфраструктури морської освіти. Це потрібно як державі, так і судноплавним компаніям для забезпечення належної інфраструктури, іï оновлення та розвитку людського капіталу, який визначатиме стратегічне бачення морської освіти та переконуватиме власників суден наймати українських моряків.

3. Залучення випускників інших морських університетів для накопичення резерву потенціалу людських ресурсів. Університетам потрібні студенти, які отримали досвід роботи в морі, з метою залучення їх до здійснення досліджень на магістерських та докторських програмах для забезпечення балансу практичного професійного досвіду та академічно кваліфікованого людського капіталу.

4. Установлення більш вигідних партнерських угод з міжнародними морськими інститутами та представниками морської галузі. Партнерські угоди з іншими міжнародними університетами та компаніями допоможуть студентам легко інтегруватися у світову галузь судноплавства завдяки програмам обміну.

5. Державний бюджет для морської освіти. Дефіцит бюджету морських закладів вищої освіти компенсуеться стейкхолдерами, що зацікавлені у підготовці морських фахівців в Україні і постачають українським ЗВО обладнання та тренажери. Проте залежність від іноземного капіталу може впливати на програми підготовки морських фахівців, що не ураховують національних соціальних та політичних аспектів. Отже, рекомендуеться збільшення державного фінансування морських закладів освіти для використання коштів, зокрема, на проведення досліджень, удосконалення матеріально-технічної бази вітчизняних морських ЗВО та підвищення їх конкурентоспроможності на ринку освітніх послуг.

У дослідженні T. N. M. Tran (Tran T. N. M., 2018) пропонуються такі рішення для інтеграції вимог четвертої промислової революції (4.0) в морську освіту:

I. На національному рівні:

1) перегляд стратегічного плану стосовно наслідків промислової революції 4.0, в якому співробітництво між урядом - морською галуззю - університетами повинно бути підкреслено та підтримано конкретними заходами від усіх зацікавлених сторін;

2) розробка відповідної політики, нормативно-правових актів для заохочення судноплавних компаній до участі у навчанні курсантів, щоб студенти мали більше можливостей для доступу до сучасних суден;

3) розробка сильної, всебічної й стійкої політики та правових рамок для підтримки міжнародного співробітництва й інвестицій у морську освіту.

II. На інституціональному рівні:

1) перегляд стратегічного плану з урахуванням усіх нових тенденцій, включаючи наслідки промислової революції 4.0;

2) щодо розвитку людського капіталу:

- розробка комплексного та стратегічного підходу до розвитку людських ресурсів 3 урахуванням інтересів людей та цілей організації, починаючи з побудови основних цінностей до вимог щодо постійного професійного розвитку кожної людини;

- збільшення уваги до підтримки викладачів у вдосконаленні їх професійної підготовки, 
створення команди підтримки у морській освіті;

- розробка ефрективної системи управління знаннями для накопичення та використання позитивного досвіду від окремих програм безперервного професійного розвитку;

- використання переваг мультидисциплінарних установ для сприяння фрормуванню міждисциплінарних робочих i дослідницьких груп між напрямами морської справи та інформаційними технологіями для забезпечення якісного персоналу з достатніми знаннями та навичками, як для досліджень, так і для викладання;

3) щодо розробки освітніх програм:

- інтеграція модулів для набуття цифрової грамотності в освітню програму всіх морських спеціальностей, приділяючи достатньо уваги етичній та професійній поведінці, кібербезпеці, а також конфріденційності інфрормації;

- забезпечення у середньостроковій перспективі навчання за бакалаврською програмою, організувавши навчання на борту судна;

- перегляд існуючих довгострокових програм 3 метою забезпечення міждисциплінарного підходу для реалізації дуального навчання.

4) щодо інфраструктури:

- забезпечення консультантів керівництвами для проведення відповідної політики щодо навчання на судні;

- доцільне інвестування в інфраструктуру, зокрема з урахуванням можливостей сучасних технологій, наприклад, застосування симуляторів у освітньому процесі;

- продовження розробки засобів підтримки електронного навчання в поєднанні з підвищенням кваліфікації викладачів, оскільки освіта у період промислової революції 4.0 повинна бути індивідуальною;

- стратегічне мислення про промисловість та взаємну вигоду для довгострокових інвестицій.

Таким чином, робиться акцент на удосконаленні не лише освітніх технологій, а й на широкому застосуванні технологічних надбань четвертої промислової революції, яка визначає пріоритетом інформаційні та цифрові технології. Професійна підготовка має базуватися на використанні цих технологій, i лише за цих умов випускники морських закладів вищої освіти будуть конкурентоспроможними на ринку праці. Це у свою чергу підвищить престиж морської освіти в Україні та зміцнить імідж України як держави, що здійснюе ефективну підготовку морських фрахівців.

Обговорення / Discussion. Ірунтуючись на аналізі освітніх програм університетів, що $є$ членами IAMU (Members, 2019), ми дійшли тих же висновків, що й Л. Кошарська, В. Бредньова й А. Левіцкі стосовно певного набору базових принципів професійної підготовки морських фрахівців у різних країнах, незважаючи на те, що вона має свої особливості та національні риси. В основному превалюе англо-саксонська модель, що пропонуе три основі ступені вищої освіти: бакалаврат (3-4 роки навчання) - магістратура (1-1,5 роки) - аспірантура (3-4 роки). Також підтверджуються думка В. Сфентьєва про те, що при деяких відмінностях освіти у різних країнах, загальним залишається вирішальна роль вищої освіти у розвитку освітнього потенціалу людини, людського капіталу як матеріальної цінності та соціального ресурсу держави (Єфентьєв В., 2005). Задля підвищення рівня ефективності професійної англомовної підготовки майбутніх морських фрахівців доцільним вважаемо також впровадження структурної моделі фрормування комунікативної компетентності майбутніх моряків на основі гейміфікованого підходу у освітньому електронному педагогічному середовищі MOODLE (Юрженко А., 2019). Доведено, що використання симуляційних технологій змішаної реальності при підготовці майбутніх судноводіїв $є$ досить актуальним, і потребуе комплексного підходу та першочергового вирішення на шляху розвитку цифровізації суспільства (Попова Г., 2019). Досліджуючи українську систему морської освіти, I. Рябуха встановлює, що стандарти підготовки сертифікації та несення вахти моряків відрізнялися у кожній окремій країні та визначались національним законодавством кожної окремої країни, що, проте, не забезпечувало достатнього рівня підготовки моряків для задоволення постійно зростаючих вимог стосовно безпеки морського транспорту (Рябуха I., 2019). G. Emad та W. M. Roth висвітлили суперечності в діючій системі морської освіти та навчання, яка базується на освіті, навчанні та ощінці на основі компетентностей, та теоретизували неспроможність зробити морську освіту корисною без висвітлення професійних компетентностей (G. Emad, \& W. M. Roth, 2008).

Проте науковці не визначили тих підходів, засобів, методів навчання у морській освіті за кордоном, що спрямовані на підвищення едективності профресійної підготовки морських фрахівців і які доцільно реалізувати у процесі професійної підготовки майбутніх морських фрахівців в Україні.

Висновки / Conclusions. Таким чином, у процесі наукового пошуку встановлено, що для вдосконалення професійної підготовки майбутніх морських фрахівців в Україні можуть бути використані такі підходи як, міждисциплінарний, дуальний, інформативний, дослідницький, 
інтегративний, а також принцип мобільності. Ефективними засобами освітнього процесу визнаються засоби віртуальної та доповненої реальності, мобільні технології та електронне навчання. Запропоновані рішення для інтеграції вимог четвертої промислової революції в морську освіту можуть бути доцільними для обговорення та впровадження у процес професійної підготовки майбутніх морських фахівців в Україні.

Перспективою подальших наукових досліджень у визначеному напрямі може стати аналіз змісту та методів навчання у закордонних морських освітніх закладах з метою узагальнення сучасного досвіду професійної підготовки майбутніх морських фахівців у світі.

Список використаних джерел і літератури:

About IAMU. Взято 3: https://iamu-edu.org/about-iamu [in English].

Emad, G., \& Roth, W. M. (2008). Contradictions in the Practices of Training for and Assessment of Competency. Education Training, 50 (3), 260-272. doi: https://doi.org/10.1108/00400910810874026 [in English].

International Association of Maritime Universities. (2004). International Association of Maritime Universities Annual General Assembly no 5, 2004: Advances in International Maritime Research [in English].

International Maritime Organization. (2017). STCW: Including 2010 Manila Amendments: STCW Convention and STCW Code: International Convention on Standards of Training, Certification and Watchkeeping for Seafarers. London [in English].

Members. Взято з https://iamu-edu.org/about-iamu/members [in English].

MSc and Phd in Maritime Affairs Taught in Malmo. Academic Handbook. Взято 3 https://www.wmu.se/sites/default/files/documents/files/WMU-Academic-Handbook-2018-Online_0.pdf [in English].

Ngcobo, L. A. (2018). Response to Technology Advancement in Maritime Education and Training: a Case Study of the South African National Maritime Institutes. (MSc dissertation). Malmö: World Maritime University [in English].

Redefining Seafaring Pedagogy - Impacts of Virtual Reality on Maritime Education and Training. Взято 3 https://iamu-edu.org/download/final-report-of-research-project-fy2017 [in English].

Tran, T. N. M. (2018). Integrating Requirements of Industry 4.0 into Maritime Education and Training: Case Study of Vietnam. (MSc dissertation). Malmö: World Maritime University [in English].

Ефентьев, В. П. (2005). Теория и практика управления качествол непрерывной пробессиональной подготовки морских специалистов в акаделическол колплексе. (Автореф. дисс. д-ра пед. наук). Калининград [in Russian].

Костылев, И. И., \& Овсянников, М. К. (2015). Морское образование в международной индустрии. Высшее образование сегодня, 5, 24-28 [in Russian].

Кошарская, Л. В., Бреднёва, В. П., \& Левітцкі, А. (2019). О проблемах отечественного и зарубежного морского образования. Вісник Одеського національного морського університету. Взято 3 http://mx.ogasa.org.ua/handle/123456789/7631 [in Russian].

Макаренко, М. В., Носовська, О. Б., \& Кравченко, А. В. (2017). Рівень професійної підготовки моряків торговельного фрлоту як головний чинник зниження аварійності на морі. Вісник Приазовського державного технічного університету, 34, 259-266 [in Ukrainian].

Попова, Г. В. (2019). Симуляційні технології змішаної реальності у підготовці майбутніх судноводіїв. Науковий огляд, 6 (59), 103-110 [in Ukrainian].

Рябуха, I. М. (2019). Вплив регуляторних актів Свропейського Союзу на розвиток української системи морської освіти (кінець XX - початок XXI століття). Педагогічні науки, LXXXVI, 7-82 [in Ukrainian].

Юрженко, А. Ю. (2019). Експериментальна перевірка ефективності моделі фрормування комунікативної компетентності в системі професійної підготовки майбутніх суднових механіків. Інноваційна педагогіка, 9 (3), 107-109 [in Ukrainian].

References:

About IAMU. Retrieved from: https://iamu-edu.org/about-iamu [in English].

Emad, G., \& Roth, W. M. (2008). Contradictions in the Practices of Training for and Assessment of Competency. Education Training, 50 (3), 260-272. doi: https://doi.org/10.1108/00400910810874026 [in English].

International Association of Maritime Universities. (2004). International Association of Maritime Universities Annual General Assembly no 5, 2004: Advances in International Maritime Research [in English].

International Maritime Organization. (2017). STCW: Including 2010 Manila Amendments: STCW Convention and STCW Code: International Convention on Standards of Training, Certification and Watchkeeping for Seafarers. London [in English].

Members. Retrieved from https://iamu-edu.org/about-iamu/members [in English].

MSc and Phd in Maritime Affairs Taught in Malmo. Academic Handbook. Retrieved from https://www.wmu.se/sites/default/files/documents/files/WMU-Academic-Handbook-2018-Online_0.pdf [in English].

Ngcobo, L. A. (2018). Response to Technology Advancement in Maritime Education and Training: a Case Study of the South African National Maritime Institutes. (MSc dissertation). Malmö: World Maritime University [in English].

Redefining Seafaring Pedagogy - Impacts of Virtual Reality on Maritime Education and Training. Retrieved from https://iamu-edu.org/download/final-report-of-research-project-fy2017 [in English].

Tran, T. N. M. (2018). Integrating Requirements of Industry 4.0 into Maritime Education and Training: Case Study of Vietnam. (MSc dissertation). Malmö: World Maritime University [in English]. 
Efentyev, V. P. (2005). Teoriya i praktika upravleniya kachestvom neprery'vnoj professional'noj podgotovki morskix specialistov $v$ akademicheskom komplekse [The Theory and Practice of Quality Management of Continuing Professional Training of Maritime Specialists in the Academic Complex]. (Extended abstract of Doctor's thesis). Kaliningrad [in Russian].

Kosty'lev, I. I. \& Ovsyannikov, M. K. (2015). Morskoye obrazovaniye v mezhdunarodnoj industrii. [Maritime Education in International Industry]. Vy'shee obrazovaniye segodnya - Higher Education Today, 5, 2428 [in Russian].

Kosharskaya, L. V., Brednyova, V. P. \& Levitscy, A. O problemax otechestvennogo i zarubezhnogo morskogo obrazovaniya [About Problems of Domestic and Foreign Marine Education]. Visnyk Odeskoho Natsionalnoho Morskoho Universytetu - Bulletin of Odesa National Maritime University. Retrieved from http://mx.ogasa.org.ua/handle/123456789/7631 [in Russian].

Makarenko, M. V., Nosovska O. B., \& Kravchenko A. V. (2017). Riven profesiinoi pidhotovky moriakiv torhovelnoho flotu yak holovnyi chynnyk znyzhennia avariinosti na mori [The Level of Professional Training of Seamen of the Merchant Fleet as the Main Factor in Reducing the Accident Rate at Sea]. Visnyk Pryazovskoho Derzhavnoho Tekhnichnoho Universytetu - Bulletin of the Pryazovia State Technical University, 34, $259-266$ [in Ukrainian].

Popova, H. V. (2019). Symuliatsiini tekhnolohii zmishanoi realnosti u pidhotovtsi maibutnikh sudnovodiiv [Mixed Reality Simulation Technologies in the Preparation of Future Navigators]. Naukovyi ohliad - Scientific Review, 6 (59), 103-110 [in Ukrainian].

Riabukha, I. M. (2019). Vplyv rehuliatornykh aktiv Yevropeiskoho Soiuzu na rozvytok ukrainskoi systemy morskoi osvity (kinets XX - pochatok XXI stolittia) [Influence of Regulatory Acts of the European Union on the Development of Ukrainian Maritime Education System (End of the 20th - Beginning of the 21 $1^{\text {st }}$ Century)]. Pedahohichni nauky - Pedagogical sciences, LXXXVI, 78-82 [in Ukrainian].

Yurzhenko, A. Yu. (2019). Eksperymentalna perevirka efektyvnosti modeli formuvannia komunikatyvnoi kompetentnosti v systemi profesiinoi pidhotovky maibutnikh sudnovykh mekhanikiv [Experimental Verification of the Effectiveness of the Model of Communicative Competence Formation in the System of Training of Future Ship Engineers]. Innovatsiina pedahohika - Innovative Pedagogy, 9 (3), 107-109 [in Ukrainian].

Дата надходження статті: «12» вересня 2019 р.

Стаття прийнята до друку: «14» листопада 2019 р.

Волошинов Сергій - завідувач кафедри інноваційних технологій та технічних засобів судноводіння Херсонської державної морської академії, кандидат педагогічних наук, доцент

Voloshynov Serhii - Head of the Department of Innovative Technologies and Technical Means of Navigation of Kherson State Maritime Academy, Candidate of Pedagogical Sciences, Associate Professor

\section{Цитуйте ию статтю як:}

Волошинов, С. (2019). Аналіз підходів та засобів навчання у морських закладах освіти за кордоном. Педагогічний дискурс, 27, 77-83. doi: 10.31475/ped.dys.2019.27.09.
Cite this article as:

Voloshynov, S. (2019). Analysis of Approaches and Teaching Tools in Maritime Educational Institutions Abroad. Pedagogical Discourse, 27, 77-83. doi: 10.31475/ped.dys.2019.27.09. 